\title{
The Blood Groups, Abnormal Hemoglobins, and Hemoglobin Values of Pregnant Women in Liberia ${ }^{1}$
}

\author{
FRANK B. LIVINGSTONE,2 HENRY GERSHOWITZ, ESTHER BACON, \\ FRANKLIN J. KELLER AND ABNER R. ROBINSON \\ Department of Human Genetics, University of Michigan, Ann Arbor, \\ Michigan, The Lutheran Mission Hospital, Zorzor, Liberia, and Child \\ Research Center, Detroit, Michigan
}

During the course of a survey of the blood groups and abnormal hemoglobins of Liberia, we have examined the blood of 117 women attending an antenatal clinic at the Lutheran Mission Hospital, Zorzor, Liberia. The clinic was scheduled weekly, and the women were given iron and vitamin supplements at each attendance, which in some cases was irregular. The great majority of these women were in the 5 th to 9th month of pregnancy; however, a more recent follow-up of these women by one of us (E.B.) has found that one was not pregnant and 4 others were stated to have aborted but could possibly not have been pregnant.

Zorzor is situated in the central interior of Liberia about 5 miles from the Guinea border. It is in the territory of the Loma tribe, but with the opening up of the country in recent years immigrants from other tribes have settled in the area. In addition to the Loma, who constitute the majority of our sample of pregnant women, two other tribes are represented, the Kpelle, who inhabit the country south of Zorzor, and the Mandingo, who have come into the area as cola nut farmers and traders from Guinea to the north.

\section{METHODS}

Blood was collected in $10 \mathrm{ml}$ "Venules" containing oxalate on 4 and 5 June, 1958 , packed in iced thermos jugs, and airshipped to the Child Research Center, Detroit, Michigan, where the abnormal hemoglobins and hemoglobin values were determined. The blood grouping was done at the Department of Human Genetics of the University of Michigan on 12 and 13 June 1958. Red cell antigens are known to deteriorate, and during the past two years we have occasionally experienced this in blood samples from various parts of the world. However, considering the rather short interval between collection and testing, and also the fact that many of the results to be reported are consistent with our previous findings on these tribes, there appears to have been little loss of erythrocytic antigenic properties.

All typing sera were obtained from commercial sources, and the methods of testing were those described by the vendor of each particular serum. All tests were performed in tubes with $2 \%$ washed red cell suspensions. In order to conserve serum, a two-stage screening procedure was used for the Rh system. The samples were first tested with anti-C and anti-E, and only those positive for $\mathrm{C}$ were tested further with anti-c and anti- $\mathrm{C}^{\mathrm{w}}$ (no positives for this antigen were found on the entire survey), while only those positive for $\mathrm{E}$ were tested with anti-e. The designation of $\mathrm{D}^{\mathrm{u}}$ was made when a sample failed to react with saline anti-D but did react with a potent incomplete anti-D in the Coombs test.

\section{RESULTS}

The results, together with a control sample for the Kpelle and Loma, are shown on table 1 . The sample of pregnant women from the Kpelle tribe totalled 11 and has been included with the Loma sample, since on the basis of larger numbers of tests, these tribes have not been significantly different for any blood group frequency. Included under "Others" on table 1 are

\footnotetext{
1 This study was supported in part by Contract AT (11-1) -405 with the U. S. Atomic Energy Commission.

${ }^{2}$ National Science Foundation Postdoctoral Research Fellow.
} 
TABLE 1

The blood groups, abnormal hemoglobins, and hemoglobin values of patients attending the clinics of the Lutheran Mission Hospital, Zorzor, Liberia

\begin{tabular}{|c|c|c|c|c|c|}
\hline & Pregnan & women & & ers & \\
\hline & $\begin{array}{l}\text { Kpelle- } \\
\text { Loma }\end{array}$ & Mandingo & $\begin{array}{l}\text { Kpelle- } \\
\text { Loma }\end{array}$ & Mandingo & Kpelle-Loma \\
\hline Number & 100 & 17 & $17^{1}$ & 11 & \\
\hline $\begin{array}{l}\text { Average hemoglobin } \\
\text { value (gm \%) }\end{array}$ & 9.91 & 9.73 & 12.74 & 11.65 & 12.72 \\
\hline $\begin{array}{c}\text { Hemoglobin pattern } \\
\text { Number with AA } \\
\text { Number with AS } \\
\text { Number with AC } \\
\text { Number with SF } \\
\text { Number with AK } \\
\text { Number with AN }\end{array}$ & $\begin{array}{r}90 \\
8 \\
1 \\
1 \\
- \\
-\end{array}$ & $\begin{array}{r}12 \\
5 \\
- \\
- \\
-\end{array}$ & $\begin{array}{r}14 \\
3 \\
- \\
- \\
-\end{array}$ & $\begin{array}{r}4 \\
5 \\
2 \\
- \\
-\end{array}$ & $\begin{array}{l}513 \\
65(10.9 \%) \\
10(1.7 \%) \\
1(0.2 \%) \\
1(0.2 \%) \\
6(1.0 \%)\end{array}$ \\
\hline $\begin{array}{l}\text { Blood groups } \\
\text { Number with O } \\
\text { Number with A } \\
\text { Number with B } \\
\text { Number with AB }\end{array}$ & $\begin{array}{r}46 \\
22 \\
24 \\
9\end{array}$ & $\begin{array}{l}8 \\
6 \\
2 \\
1\end{array}$ & $\begin{array}{l}9 \\
3 \\
5 \\
2\end{array}$ & $\begin{array}{l}3 \\
4 \\
2 \\
2\end{array}$ & $\begin{array}{c}268(43.7 \%) \\
165(26.9 \%) \\
144(23.5 \%) \\
36(5.9 \%)\end{array}$ \\
\hline $\begin{array}{l}\mathrm{M} \\
\mathrm{MN} \\
\mathrm{N}\end{array}$ & $\begin{array}{l}32 \\
37 \\
31\end{array}$ & $\begin{array}{l}3 \\
6 \\
8\end{array}$ & $\begin{array}{r}4 \\
12 \\
3\end{array}$ & $\begin{array}{l}3 \\
6 \\
2\end{array}$ & $\begin{array}{l}130(21.2 \%) \\
296(48.3 \%) \\
187(30.5 \%)\end{array}$ \\
\hline $\begin{array}{l}\text { ccDee } \\
\text { CcDee } \\
\text { CCDee } \\
\text { ccDEe } \\
\text { ccDEE } \\
\text { CcDEe } \\
\text { ccDuee } \\
\text { CcDuee }\end{array}$ & $\begin{array}{l}57 \\
\frac{10}{7} \\
\frac{1}{6} \\
1\end{array}$ & $\begin{array}{r}10 \\
2 \\
\frac{3}{-} \\
- \\
-\end{array}$ & $\begin{array}{r}17 \\
- \\
-1 \\
- \\
-\end{array}$ & $\begin{array}{l}6 \\
1 \\
-3 \\
- \\
-1 \\
-\end{array}$ & $\left.\begin{array}{c}168(73.0 \%) \\
28(12.2 \%) \\
2 \\
15(6.5 \%) \\
1 \\
3 \\
2 \\
4\end{array}\right\}(2.6 \%)$ \\
\hline $\begin{array}{l}\text { ccddee } \\
\text { Ccddee } \\
\text { ccddEe }\end{array}$ & $\begin{array}{r}10 \\
5 \\
3\end{array}$ & $\frac{-}{1}$ & - & - & $\left.\frac{6}{1}\right\}(3.0 \%)$ \\
\hline
\end{tabular}

${ }^{1}$ For this category 19 specimens were blood grouped, but hemoglobin determinations were done on only 17 due to the insufficiency of red cells for two samples.

blood samples obtained at the same time as those from the pregnant women, but from persons attending the outpatient clinic at the Lutheran Hospital. These are mostly adult males, but some adult females are also included. The control samples were obtained on various surveys throughout Liberia and contain individuals from all parts of the Kpelle and Loma tribal areas. Hence the control blood group frequencies are the mean frequencies for the entire Kpelle and Loma tribes. While the percentages of the various blood groups are shown for the controls, for the Kpelle and Loma pregnant women these percentages are the same as the actual numbers. It should also be noted that the differences in numbers of tests done on the controls for the various blood group antigens are due to our having begun testing for these antigens at different times during the course of our project.

\section{DISCUSSION}

The hemoglobin values, both for the pregnant women and the other adults, approximate but are slightly higher than those found by Woodruff and Schofield ('57) in the Gambia. These increases can perhaps be explained by the fact that in addition to the iron and vitamin supplements given to the pregnant women, most of our patients were treated for hookworm and malaria. In any case, both studies indicate that the stress of pregnancy results in a decrease of 2-3 gm of hemoglobin in West Africans living under similar conditions. 
For the Kpelle and Loma pregnant women the frequencies of the sickle cell and hemoglobin $\mathrm{C}$ genes are similar to previously recorded tribial frequencies (Livingstone, '58; Neel et al., '56). For the Mandingo, however, the frequencies of the sickle cell gene, both among the pregnant women and the other patients from Zorzor, are quite high when compared to the average Mandingo frequency in Liberia (Livingstone, '58). The groups of Mandingo who have migrated into the Gambia also show great variability in their in their frequencies of the sickle cell gene (Allison, '56).

One Loma woman showed an SF pattern on paper electrophoresis. This is one of the diagnostic criteria of sickle cell anemia due to homozygosity for the sickle cell gene, but it is not sufficient evidence for this diagnosis (Edington and Leh. mann, '55). We have also found several other individuals with this electrophoretic pattern who showed no other symptoms of anemia (Neel et al., '56). It is interesting to note in this respect that this woman has had 7 full-term pregnancies and one abortion. She complained of "weakness" after childbirth and had a hemoglobin value of $8 \mathrm{gm}$ but otherwise appeared to be in normal health for a women of her age in this area. In view of the recent finding of an appreciable frequency of thalassemia in Liberia (Olesen et al., '59), we think it more likely that this woman is heterozygous for both the thalassemia and sickle cell genes.

The $A B O$ blood group gene frequencies of the Kpelle and Loma pregnant women do not differ significantly from those of the controls ( $x^{2}=0.570,2$ d.f., $.75<\mathrm{P}<$ $0.90)$, nor do the $M N$ gene frequencies $\left(x^{2}=1.896,1\right.$ d.f., $\left..10<\mathrm{P}<0.25\right)$. However, the observed number of MN heterozygotes is much lower than the expected number in a Hardy-Weinberg equilibrium, and for the Kpelle and Loma pregnant women is statistically signficant $\left(x^{2}=\right.$ $6.756,1$ d.f., $0.005<\mathrm{P}<0.01$ ). Technical error might be suspected here, but it should be noted that the other blood samples which were taken at the same time as those of the pregnant women do not show this decrease in MN heterozygotes. In addition, only two of 34 tribal samples from Liberia of our survey show a similar deviation from expected. The decrease in $\mathrm{MN}$ heterozygotes seems to be apportioned equally among the MM and NN homozygotes, and this increase in homozygotes might possibly be due to inbreeding resulting from the size of the breeding isolate in this part of Liberia. On the other hand, it may be that the MN heterozygous women are not having as much difficulty in pregnancy and hence not as likely to attend the antenatal clinic.

If the $\mathrm{Rh}$ - phenotypes on table 1 are combined, the frequency of $\mathrm{Rh}-$ among the Kpelle and Loma pregnant women is $18 \%$, while it is $3 \%$ among the controls. This difference is highly significant $\left(x^{2}=\right.$ 22.267, 1 d.f., $\mathrm{P}<<0.001$ ). Since the tribes of Liberia do not differ significantly in their $\mathrm{Ph}$ frequencies (Livingstone, et al., n.d.) and the average frequency of $\mathrm{Rh}-$ is slightly less than $5 \%$, the greatly increased frequency among pregnant women seems to be a real difference and not a statistical artifact.

The finding of a greatly increased frequency of $\mathrm{Rh}-$ among pregnant women seems to be due to two reasons. The first and most obvious reason is that these women would be more likely to have difficulty in child-bearing and hence more likely to attend the antenatal clinic. The second reason is the result of the childrearing practices of the Kpelle and Loma people. In these societies a woman's main task in life is to have as many children as posible. However, after a child is born, there are strict tabus against the mother becoming pregnant again before the child is weaned. For the Loma the mother must not cohabit with her husband until the child is three years old if it is a girl, or 4 years old if it is a boy (Schwab, ' 47 ; p. 209). Similar practices which attempt to "space" children are quite widespread among primitive peoples and are presumably efforts to give the child a maximum chance to survive. In such a society women with unsuccessful pregnancies would be almost continually pregnant, while those whose children lived would be pregnant once every 4 years at most. Since $\mathrm{Rh}-$ women would be more likely to have difficulty in child-rearing, these cultural practices of the Kpelle and Loma seem to 
TABLE 2

Outcomes of present pregnancies

\begin{tabular}{|c|c|c|c|c|c|c|c|}
\hline & $\begin{array}{c}\text { No. of } \\
\text { women }\end{array}$ & $\begin{array}{l}\text { Full-term } \\
\text { livebirth }\end{array}$ & $\begin{array}{l}\text { Full-term } \\
\text { stillbirth }\end{array}$ & $\begin{array}{c}\text { Premature } \\
\text { livebirth }\end{array}$ & $\begin{array}{c}\text { Premature } \\
\text { stillbirth }\end{array}$ & Abortion & $\begin{array}{c}\text { Neonatal } \\
\text { death }\end{array}$ \\
\hline $\begin{array}{l}\mathrm{Rh}- \\
\mathrm{Rh}+\end{array}$ & $\begin{array}{l}18 \\
89\end{array}$ & $\begin{array}{l}14(77.8 \%) \\
78(87.6 \%)\end{array}$ & $\overline{1}$ & $\begin{array}{l}2 \\
5\end{array}$ & $\begin{array}{l}2 \\
2\end{array}$ & $\overline{3}$ & $\begin{array}{l}2 \\
6\end{array}$ \\
\hline
\end{tabular}

Histories of multigravida

\begin{tabular}{|c|c|c|c|c|c|c|c|}
\hline & $\underset{\text { women }}{\text { No. of }}$ & $\begin{array}{c}\text { Total } \\
\text { conceptions }\end{array}$ & Abortions & Stillbirths & Livebirths & $\begin{array}{c}\text { Children } \\
\text { living }\end{array}$ & $\begin{array}{c}\text { Children } \\
\text { dead }\end{array}$ \\
\hline $\begin{array}{l}\mathbf{R h}- \\
\mathbf{R h}+\end{array}$ & $\begin{array}{l}14 \\
68\end{array}$ & $\begin{array}{r}34 \\
232\end{array}$ & $\begin{array}{r}3 \\
28\end{array}$ & $\begin{array}{r}4 \\
24\end{array}$ & $\begin{array}{r}27 \\
180\end{array}$ & $\begin{array}{r}14 \\
118\end{array}$ & $\begin{array}{l}13 \\
62\end{array}$ \\
\hline
\end{tabular}

be another factor increasing the frequency of $\mathrm{Rh}$ - women among the women pregnant at any one time.

In order to determine whether the foregoing explanation has any evidence in its favor, we have recorded the outcomes of these pregnancies where possible and attempted to obtain pregnancy histories from the multigravida. Table 2 shows the results of these inquires.

It is not difficult to envisage many biases in these data, and there has undoubtedly been some failure to recall previous pregnancies on the part of the multigravida. Nevertheless, the Kpelle and Loma women do remember quite accurately the number of livebirths they have had and, of course, the number who are still living. Thus, in the last two columns of the pregnancy histories there is some evidence to indicate that the $\mathrm{Rh}-$ women have had more difficulty raising viable offspring. The $\mathrm{Rh}$ - women have an average of 1.00 living children per woman, while the $\mathrm{Rh}+$ women have 1.74 , but this difference is not statistically significant $\left(x^{2}=1.908,1\right.$ d.f., $0.10<\mathrm{P}<0.25$ ). There are few of the present pregnancy outcomes of the $\mathrm{Rh}$ - women which show direct evidence for $\mathrm{Rh}$ sensitization. Two of the live-births were jaundiced but recovered. Some of these women did show histories of repeated neonatal deaths or stillbirths, and the frequencies of neonatal deaths and stillbirths are somewhat higher for the $\mathrm{Rh}$ - women, but the numbers are too small to be of real significance. Thus, although there is some evidence for $\mathrm{Rh}$ sensitization, our data seem to indicate that other factors may also be involved in increasing the frequency of $\mathrm{Rh}-$ wo- men among the women pregnant at any one time to $18 \%$ from its expected frequency of about $5 \%$. Our results also indicate that $R h$ sensitization in pregnancy may be more of a medical problem in West Africa than was previously supposed, but a more accurate estimate of its frequency there will have to await the collection of more data on this problem.

Since submitting this manuscript we have tested the sera of the $19 \mathrm{Rh}$ - women and none had demonstrable anti-D antibodies. This does not preclude the presence of anti-V.

\section{LITERATURE CITED}

Allison, A. C. 1956 The sickle-cell and haemoglobin $\mathrm{C}$ genes in some African populations. Ann. Human Genet., 21: 67-89.

Edington, G. M., and H. Lehmann 1955 Expression of the sickle cell gene in Africa. Brit. Med. J., 2: 1328.

Livingstone, F. B. 1958 The distribution of the sickle cell gene in Liberia. Am. J. Human Genet., 10: 33-41.

Livingstone, F. B., H. Gershowitz, M. Solomon, G. Binson, W. W. Zuelzer and J. V. Neel n.d. The distribution of several blood group genes in Liberia, the Ivory Coast, and Upper Volta. In preparation.

Neel, J. V., J. Hiernaux, J. Linhard, A. R. Robinson, W. W. Zuelzer and F. B. Livingstone 1956 Data on the occurrence of hemoglobin $C$ and other abnormal hemoglobins in some African populations. Am. J. Human Genet., 8: $138-149$.

Olesen, E. B., K. Olesen, F. B. Livingstone, F. Cohen, A. R. Robinson, W. W. Zuelzer and J. V. Neel 1959 Thalassemia in Liberia. Brit. Med. J., 1: 1385-1387.

Schwab, G. 1947 Tribes of the Liberian Hinterland. Papers of the Peabody Museum of American Archaeology and Ethnology, Harvard Univ., Cambridge.

Woodruff, A. W., and F. D. Schofield 1957 Hemoglobin values among Gambians. Trans. Roy. Soc. Trop. Med. Hyg., 51: 217-220. 